\title{
ANALISIS PENGARUH PERENCANAAN PAJAK TERHADAP LABA PERUSAHAAN PADA PT SARI ENESIS INDAH TAHUN 2017-2020
}

\begin{abstract}
Penulis: Abstrak: Perencanaan pajak merupakan tindakan yang dilakukan Aluinahot Telaumbanua ${ }^{1}$ Lorina Siregar

Sudjiman $^{2}$

Afiliasi:

${ }^{1}$ Mahasiswa Program Studi Akuntansi, ${ }^{2}$ Dosen Program Studi Akuntansi, Fakultas Ekonomi, Universitas Advent Indonesia, Bandung

perusahaan sebagai langkah untuk melakukan penghematan pajak. Tindakan ini merupakan hal yang legal dalam undang-dalam perpajakan yang berlaku di Indonesia asalkan tidak melanggar undang-undang yang ada. Hal ini dilakukan karena pajak merupakan salah satu unsur pengurang dalam laba perusahaan. Penelitian ini bertujuan untuk mengetahui pengaruh perencanaan pajak terhadap laba perusahaan pada PT sari Enesis Indah. Teknik pengumpulan data yang dilakukan meliputi deskriptif kuantitatif (non statistik), deskriptif eksploratif dan wawancara dengan pihak akuntansi dan perpajakan pada perusahaan. Hasil penelitian ini menunjukkan bahwa perencanaan pajak perpengaruh positif terhadap laba perusahaan, dimana apabila perencanaan pajak yang dilakukan semakin tinggi maka laba yang akan diperoleh perusahaan juga akan semakin tinggi. Akan tetapi banyak juga faktor yang dapat mempengaruhi tinggi rendahnya laba yang diperoleh perusahaan perusahaan.
\end{abstract} Korespondensi: aluinahot02@email.co $\underline{\mathrm{m}}$

Kata kunci: laba perusahaan dan perencanaan pajak

Histori Naskah:

Submit: 99-00-9999

Accepted: 99-00-9999

Published: 99-00-9999

\section{Pendahuluan}

Pada akhir tahun 2019 Dunia dikejutkan dengan adanya virus Covid-19, peristiwa ini memberikan dampak buruk terhadap pertumbuhan ekonomi pada berbagai negar dan juga perusahan dari berbagai sektor bisnis. Ditengah pandemi wabah Covid-19, dilansir dari ekonomi.bisnis.com (Nugroho, 2020) sektor industri manufaktur indonesia anjlok ke 45,3 persen pada bulan Maret 2020 dari 51,9 persen pada bulan Februari 2020. Seperti yang dialami oleh PT Pakuwon Jati Tbk (PWON) dilansir dari cnbcindonesia.com (Wareza, 2020) PT Pakuwon Jati Tbk menuliskan penurunan laba bersih yang derastis sepanjang kuartal I-2020. Laba bersih perusahaan anjlok hingga 90,73\% secara year on year dari Rp 720,95 miliar di periode yang sama tahun sebelumnya menjadi Rp 66,76 milliar di akhir maret. Berdasarkan laporan keuangan perusahaan yang dipublikasikan, nilai laba persaham jugak anjlok dari harga sebelumnnya Rp 14,97 menjadi Rp 1,39.

Laba perusahaan menjadi salah satu alat ukur terhadap nilai perusahaan. Apabila laba suatu perusahaan semakin tinggi dalam setiap periodenya maka perusahaan tersebut memiliki kinerja dan nilai yang baik. Jika laba perusahaan semakin menurun setiap periodenya maka perusahaan tersebut memiliki kinerja dan nilai yang buruk, hal ini dapat memberikan ancaman besar bagi perusahaan karena laba merupakan salah satu sumber keungan perusahaan untuk memenuhi setiap kebutuhan perusahaan dalam menjalankan 
aktivitasnya. Pada perhitungan laba biasanya perusahaan akan melakukannya di akhir periode yang nantinya akan dicantumkan dalam laporan keuangan perusahaan tersebut. (Feriyana, 2017) menyatakan bahwa laba merupakan keuntungan bagi perusahaan atas apa yang telah dikorbankan oleh perusahaan demi kepentingan pihak lain.

Setiap perusahan pastinya menginginkan laba yang besar, akan tetapi banyak faktor yang dapat menyebabkan rendah atau tingginya laba suatu perusahaan. Salah satu faktor yang mempengaruhi laba iyalah pajak. Dalam undang-undang KUP pasal 1 no. 28 tahun 2007 menyatakan bahwa pajak merupakan iuran wajib kepada negara yang terutang oleh badan atau orang pribadi bersifat memaksa berdasarkan undang-undang, dengan tidak memperoleh imbalan lansung dan digunakan untuk kepentingan negara bagi sebesar-besarnya kesejahteraan rakyat. Semakin meningkat pendapatan suatu perusahaan berarti akan semakin meningkat pula pajak yang harus dibayar oleh perusahaan kepada negara, dengan besarnya beban pajak perusahaan maka laba perusahaan tersebut jugak akan berkurang.

Salah satu cara untuk memperkecil beban pajak perusahaan guna meningkatkan laba iyalah dengan melakukan perencanaan pajak (tax planing). Menurut (Riyanto \& Margie, 2021) perencanaan pajak merupakan rangkaian strategi yang dilaksanakan oleh manajemen perusahaan untuk memperkecil biaya pajak yang harus disetorkan. Perusahaan melakukan perencanaan pajak bertujuan untuk dapat menekan beban atas pebayaran pajak hingga sekecil mungkin dengan melakukan penghindaran pajak, akan tetapi tanpa melakukan pelanggaran atas UU dan peraturan pajak yang berlaku dengan memanfaatkan peraturan dan hal-hal yang tidak terdapat dalam UU perpajakan. Perencanaan pajak menurapakan suatu tujuan manajemen pajak dalam perusahaan yang dipakai untuk menafsirkan besaran pajak yang nantinya dibebankan pada perusahaan dan hal apa saja yang boleh dilakukan untuk melaksanakan penghindaran pajak. Dilansir dari Nasional.kontan.co.id (Santoso, 2020) ditengah pandemi covid 19 penghindaran pajak mengakibatkan negara mengalami kerugian sebesar 68,7 triliun pertahunnya, dari angka tersebut Rp 67,6 triliun adalah dampak dari penghindaran pajak korporasi di indonesia dan Rp 1,1 triliun adalah dari wajib pajak orang pribadi. Pada penerapannya badan multi nasional mentransfer labanya ke negara yang merupakan surga pajak, sehingga tidak perlu melaporkan banyaknya laba pada tempat bisnisnya. Untuk wajib pajak orang pribadi yang termasuk dalam golongan orang kaya menutupi aset dan pendapatan yang dideklarasikan diluar negeri dan tidak dapat dijangkau oleh hukum.

Berdasarkan penelitian terdahulu yang dilakukan (Feriyana, 2017) menyimpulkan bahwa terdapat perubahan yang signifikan antara laba sebelum pajak dan laba setelah pajak ketika setelah menggunakan perencanaan pajak dan saat belum menggunakan perencanaan pajak.

Menurut (Yuliza \& Fitri, 2020) mengungkap bahwa secara simultan bahwa nilai signifikan atas pengaruh perecanaan pajak perusahaan terhadap laba perusahaan.

Dalam penelitian yang dilakukkan (Muiz, Enong dan Ningsih, 2018) mengatakan bahwa perencanaan pajak berpengaruh secara positif dan tidak signifikan dengan manajemen laba

Menurut (Suputra, 2017) Perencanaan pajak berpengaruh positif terhadap laba, dimana semakin tinggi perencanaan pajak maka semakin tinggi peluang perusahaan melaksanakan manajemen laba. Meskipun pengaruhnya lemah karena banyak faktor-faktor yang mempengaruhi manajemen laba.

Dari uraian diatas peneliti tertarik untuk melaksanakan penelitian yang berjudul Analisi Pengaruh Perencanaan Pajak Terhadap Laba Perusahaan PT Sari Enesis Indah Tahun 2017-2020. Berdasarkan judul diatas timbul rumusan masalah, yaitu: bagaimana pelaksanaan perencanaan pajak pada PT Sari Enesis 
Indah, bagaimana perolehan laba perusahaan pada PT Sari Enesis Indah dan apakah perencanaan pajak yang dilakukan oleh manajemen pajak berpengaruh terhadap laba perusahaan pada PT Sari Enesi Indah dari tahun 2017 hingga 2020.

\section{Studi Literatur}

\section{Laba}

(Hidayat et al., 2021) laba adalah Keuntungan yang diperoleh suatu perusahaan sebagai akibat dari terjadinya kelebiha selisih pendapatan yang diperoleh perusahaan dengan pengeluaran dan biaya-biaya operasional perusahaan. (Puspitaningtyas, 2017) menyatakan bahwa laba dipandang sebagai indikator terbaik dalam menentukan pencapaian kinerja suatu perusahaan dalam periode tertentu. Laba dapat digunakan sebagai penilaiaan baik buruknya kinerja suatu perusahaan semakin tinggi laba perusahaan maka semakin baik juga nilai perusahaan tersebut. Dengan mengetahui laba suatu perusahaan para investor juga dapat membuat pertimbangan apakah perusahaan tersebut layak dijadikan sebagai suatu tabungan investasi yang baik atau tidaknya dan para investor akan cendrung untuk memilih melakukan investasi di perusahaan yang memperoleh lama yang semakin tinggi dalam setiap periodenya. Ada beberapa cara dalam mengukur laba perusahaan dalam penelitian ini untuk mengukur laba perusahaan dengan menggunakan laba setelah pajak.

\section{Perencanaan Pajak}

Menurut (Astutik 2016 dalam Achyani \& Lestari, 2019) Perencanaan pajak merupakan suatu proses mengorganisasi usaha wajib pajak atau sekelompok wajib pajak dengan berbagai cara sehingga beban pajak berupa PPh ataupun hutang pajak lain-lain berada pada nilai yang sekecil mungkin. Tujuan utama perencanaan pajak iyalah untuk mengurangi besaran jumlah pajak yang akan disetorkan oleh si wajib pajak dengan memanfaatkan celah-celah pada peraturan perpajakan yang berlaku yang berguna untuk meningkatkan besaran laba setelah pajak, itu seab pajak adalah salah satu faktor pengurang laba. (Dewi et al., 2017) mengatakan perencanaan pajak dapat dikur dengan beberapa cara salah satunya dengan mengandalkan laba, laba bersih perusahaan dan laba sebelum pajak pada laporan keuangan dengan rumus tax retentation rate atau tingkat retensi pajak.

\section{Metode Penelitian}

Metode yang digunakan oleh penulis dalam penelitian ini iyalah Deskriptif kuantitatif (non statistik) untuk mengukur perencanaan pajak dan laba perusahaan, dimana hasil dari penelitian akan dianalisis dan diolah kemudian disimpulkan. Dengan menggunakan metode ini maka dapat diketahui hubungan antara variabel yang diteliti yang nantinya akan memperoleh kesimpulan terhadap objek yag diteliti.

Penelitian yang digunakan bersifat deskriptif eksploratif, yang akan digunakan untuk mengamati dan menjelaskan fenomena yang berhubungan dengan pengaruh perencanaan pajak terhadap laba perusahaan PT Sari Enesis Indah pada tahun 2017-2020.

Penulis tidak melkukan penarikan sampel dalam penelitia ini, disesuaikan pada sifat dan metode penelitian. Akan tetapi penulis mengumpulkan data tentang laporan keuangan PT Sari Enesis Indah dari tahun 2017 sampai dengan 2020 untuk kepentingan dalam pembahasan penelitian, dengan cara melakukan wawancara dengan pihak akuntansi dan pajak pada perusahaan. Oleh sebab itu penulis meyakini bahwa informasi dan data yang disampaikan adalah benar. 
\. • P Jurnal Audit \& Perpajakan

Volume : 1 | Nomor 1 | November 2021 | E-ISSN : 2809-1809. | DOI: 10.47709/jap.v1n1.1205

\section{Definisi Operasional}

\section{Laba}

Laba merupakan penghasilan bersih atau imbalan yang diperoleh perusahan dari aktivitas yang dilakukan, mulai dari tahap produksi hingga ketahap pemasaran dan sudah dikurangi dengan biaya operasi perusahaan. Menurut Feriyana (2017) untuk mengukur laba menggunakan rumus:

$$
\text { Laba Setelah Pajak = Penghasilan sebelum pajak - Beban pajak. }
$$

\section{Perencanaan pajak}

Perencanaan pajak merupakan bagian dari manajemen laba, perencanaan pajak dapat diukur dengan menggunakan rumus tax retention rate dengan menganalisis suatu ukuran dari efektivitasa manajemen pajak pada laporan keuangan perusahaan pada periode berjalan. Menurut (Yuliza \& Fitri, 2020) rumus tax retention rate adalah:

$$
\boldsymbol{T} \boldsymbol{R} \boldsymbol{R}=\frac{\text { Laba bersih perusahaan }}{\text { Laba seelum pajak }}
$$

Keterangan:

TRR: Tex Retentio Rate (tingkat retensi pajak).

\section{Hasil}

\section{Pelaksanaan Perencanaan Pajak Pada PT Sari Enesis Indah}

Dari sisi perusahaan pajak adalah beban sebagai pengurang bagi laba. Oleh sebab itu perusahaan akan menggunakan berbagai macam usaha agar mampu memperkecil besarnya pajak yang harus dibayar, dimana caranya adalah dengan melaksanakan perencanaan pajak.

Dalam penelitian ini penulis menggunakan TRR (tax retantion rate) untuk mengukur efektivitas perencanaan pajak pada PT Sari Enesis Indah, dimana apabila TRR semakin tinggi, maka akan mencerminkan perencanaan pajak yang dilakukan oleh perusahaan semakin efektif. Sebaliknya ketika TRR semakin kecil maka perencanaan pajak pada perusahaan kurang efektif.

Tabel 1.

Perhitungan TRR (tax retantion rate)

\begin{tabular}{|l|r|r|r|r|}
\hline Keterangan & \multicolumn{1}{|c|}{$\mathbf{2 0 1 7}$} & \multicolumn{1}{|c|}{$\mathbf{2 0 1 8}$} & \multicolumn{1}{c|}{$\mathbf{2 0 1 9}$} & \multicolumn{1}{|c|}{$\mathbf{2 0 2 0}$} \\
\hline Laba Sebelum Pajak & 275.408 .659 .834 & 301.774 .194 .364 & 90.597 .531 .000 & 128.685 .799 .000 \\
\hline Laba Bersih & 210.118 .425 .334 & 228.963 .072 .364 & 56.550 .941 .750 & 55.990 .219 .000 \\
\hline TRR & 0,762933255 & 0,758723167 & 0,624199590 & 0,435092446 \\
\hline
\end{tabular}

(Sumber: Data diolah penuli) 
\. • P Jurnal Audit \& Perpajakan

Volume : 1 | Nomor 1 | November 2021 | E-ISSN : 2809-1809. | DOI: 10.47709/jap.v1n1.1205

\section{Perolehan Laba Perusahaan pada PT Sari Enesis Indah}

Dalam melakukan perhitungan laba setelah pajak perusahaan pada PT Sari Enesis Indah adalah dengan mengurangkan laba perusahaan yang diperoleh dalam satu periode dengan jumlah beban pajak badan. Agar dapat menghitung pajak penghasilan atau $\mathrm{PPh}$, haruslah mengetahui dasar apa saja yang akan dikenakan pajak. Bagi wajib pajak (WP) dalam negeri dan bentuk usaha tetap (BUT) luar negeri yang menjadi landasan pengenaan pajaknya iayalah penghasilan kena pajak (PKP). Untuk menghitung besarnya PKP wajib pajak badan adalah sebesar penghasilan nettonya (PKP WP Badan = Penghasilan Netto).

Dalam UU Perpajakan pasal 17 ayat 1b UU Nomor 36 Tahun 2008 (UU No. 36 Tahun 2008) bahwa wajib pajak badan dalam negeri dan BUT adalah sebesar 28\% . Pada pasal 17 ayat 2a undang-undang Nomor 36 tahun 2008 meyatakan bahwa tarif sebagai mana dinyatakan pada ayat $1 \mathrm{~b}$ menjadi $25 \%$ dan mulai berlaku sejak tahun 2010. Di dalam peraturan pemerintahan RI Nomor 30 Tahun 2020 (Peraturan Presiden Republik Indonesia, 2020) tentang penurunan tarif pajak penghasilan bagi wajib pajak badan dalam negeri yang berbentuk perseroan terbuka pada pasal 2 a bahwa tarif pajak penghasilan menjadi $22 \%$ yang berlaku dalam tahun pajak 2020 dan 2022.

Tabel 2.

Perhitungan Laba Setelah Pajak

\begin{tabular}{|l|r|r|r|r|}
\hline Keterangan & \multicolumn{1}{|c|}{$\mathbf{2 0 1 7}$} & \multicolumn{1}{|c|}{$\mathbf{2 0 1 8}$} & \multicolumn{1}{c|}{$\mathbf{2 0 1 9}$} & \multicolumn{1}{|c|}{$\mathbf{2 0 2 0}$} \\
\hline Laba Sebelum Pajak & 275.408 .659 .834 & 301.774 .194 .364 & 90.597 .531 .000 & 128.685 .799 .000 \\
\hline Jumlah Beban Pajak & 65.290 .234 .500 & 72.811 .122 .000 & 34.046 .589 .250 & 31.026 .000 .120 \\
\hline Laba Setelah Pajak & 210.118 .425 .334 & 228.963 .072 .364 & 56.550 .941 .750 & 97.659 .798 .880 \\
\hline
\end{tabular}

(Sumber: Data diolah penulis)

Pada tabel 1. diperoleh perhitungan TRR pada tahun 2017 adalah sebesar 0,762933255 hal ini menerangkan bahwa pada tahun 2017 PT Sari Enesis Indah memiliki manajemen pajak yang baik dan perencanaan pajak yang dilakukan cukup efektif karena selisih antara laba bersih dan laba sebelum pajak kecil yang berarti beban pajak yang akan dibayar juga kecil. Dimana pada tahun 2017 beban pajak pada perusahaan ini adalah sebesar 65.290.234.500 dengan laba sebelum pajak sebesar 275.408.659.834 dan pada Tabel 2. Perhitungan laba setelah pajak dapat dilihat bahwa perolehan laba perusahaan setelah pajak adalah sebesar 210.118.425.334. 


\section{- 1 - D Jurnal Audit \& Perpajakan}

Volume : 1 | Nomor 1 | November 2021 | E-ISSN : 2809-1809. | DOI: 10.47709/jap.v1n1.1205

Tabel 3.

Perhitungan keseluruhan.

\begin{tabular}{|l|r|r|r|r|}
\hline Keterangan & \multicolumn{1}{|c|}{$\mathbf{2 0 1 7}$} & \multicolumn{1}{c|}{$\mathbf{2 0 1 8}$} & \multicolumn{1}{c|}{$\mathbf{2 0 1 9}$} & \multicolumn{1}{c|}{$\mathbf{2 0 2 0}$} \\
\hline Laba Sebelum Pajak & 275.408 .659 .834 & 301.774 .194 .364 & 90.597 .531 .000 & 128.685 .799 .000 \\
\hline Laba Dikenakan Pajak & 261.160 .938 .000 & 291.244 .488 .000 & 187.981 .205 .000 & 164.207 .346 .000 \\
\hline Tarif Pajak & $25 \%$ & $25 \%$ & $25 \%$ & $22 \%$ \\
\hline Beban Pajak & 65.290 .234 .500 & 72.811 .122 .000 & 46.995 .301 .250 & 36.125 .616 .120 \\
\hline Beban Pajak Tangguhan & - & - & 12.948 .712 .000 & 5.099 .616 .000 \\
\hline Jumlah Beban Pajak & 65.290 .234 .500 & 72.811 .122 .000 & 34.046 .589 .250 & 31.026 .000 .120 \\
\hline Laba Setelah Pajak & 210.118 .425 .334 & 228.963 .072 .364 & 56.550 .941 .750 & 97.659 .798 .880 \\
\hline Laba Bersih & 210.118 .425 .334 & 228.963 .072 .364 & 56.550 .941 .750 & 55.990 .219 .000 \\
\hline TRR & 0,762933255 & 0,758723167 & 0,624199590 & 0,435092446 \\
\hline
\end{tabular}

(Sumber: Data diolah penulis)

Dalam Tabel 3. pada tahun 2018 dan 2019 terjadi penurunan dalam perhitungan TRR dari tahun sebelumnya dengan hasil 0,758723167 dan 0,624199590 hal ini menerangkan bahwa tingkat efektivitas perencanaan pajak mulai menurun jika dibandingkan dengan tahun 2017. Dengan demikian dapat diartikan bahwa perbandingan antara laba bersih dan laba sebelum pajak semakin tinggi, yang menyebabkan beban pajak juga semakin besar, dimana beban pajaknya adalah sebesar 72.811.122.000 dengan laba sebelum pajak sebesar 301.774.194.364 pada tahun 2018, dengan hal ini maka perencanaan pajak yang dilakukan masih dapat dikatakan evektif. Pada tahun 2019 penurunan TRR semakin merosot yang berarti bahwa perencanaan pajak yang dilakukan pada tahun tersebut semakin kurang evektif dari tahun-tahun sebelumnya. Dengan diperolehnya laba sebelum pajak 90.597.531.000 dan beban pajak yang dikenakan adalah sebesar 46.995.301 akan tetapi total beban pajak menjadi 34.046.589 Penurunan ini terjadi disebabkan adanya beban pajak tangguhan sebesar 12.948 .712 yang juga merupakan pengurang beban pajak badan.

Pada tahun 2020 pemerintah mengeluarkan peraturan perpajakan dimana tarif pajak PPh badan turun sebesar 3\% dari 25\% menjadi 22\%. Peraturan ini dikeluarkan akibat dampak virus Covid-19 yang menyerang negara Indonesi guna untuk meringankan beban pajak perusahaan dan untuk meningkatkan kepatuhan perusahaan dalam melakukan pembayaran pajak. Pengurangan pajak ini juga sudah merupakan suatu perencanaan pajak bagi perusahaan dimna beban pajak perusahaan akan berkurang dan akan meningkatkan laba pada perusahan. Meskipun demikian beban pajak PT sari Enesis Indah pada tahun 2020 bukannya semakin menurun dimana terdapat perhitungan TRR sebesar 0.435092446 yang berarti perbandingan antara laba bersih dengan laba sebelum pajak sebakin besar yaikni 55.990.219.000 dan 128.685.798.880, dengan jumlah beban pajak sebesar 31.026.00 dan telah dikurang dengan beban pajak tangguhan sebesar 5.099.616.000. hal ini menunjukkan bahwa perencanaan pajak pada PT Sari Enesi Indah kurang efektif. 
Salah satu faktor penyebab terjadinya peningkatan selisih antara laba bersih dan laba sebelum pajak adalah dimana perusahaan mengeluarkan biaya promosi yang juga merupakan biaya yang dikenakan pajak, sebesar 29.237.399.000 sedangkan pada tahun 2019 perusahaan ini tidak memiliki biaya promosi sama sekali. Terjadinya hal ini mengakibatkan laba setelah pajak semakin kecil yaitu 97.659.778.880 dan dengan laba bersih sebesar 55.990.219.000.

\section{Pembahasan}

Berdasarkan perhitangan pada Tabel 3. Maka diperoleh histogram perbandingan antara TRR dengan pertumbuhan laba pada perusahaan, sebagai berikut:

\section{Histogram 1.}

\section{Perbandingan TRR dengan Laba}

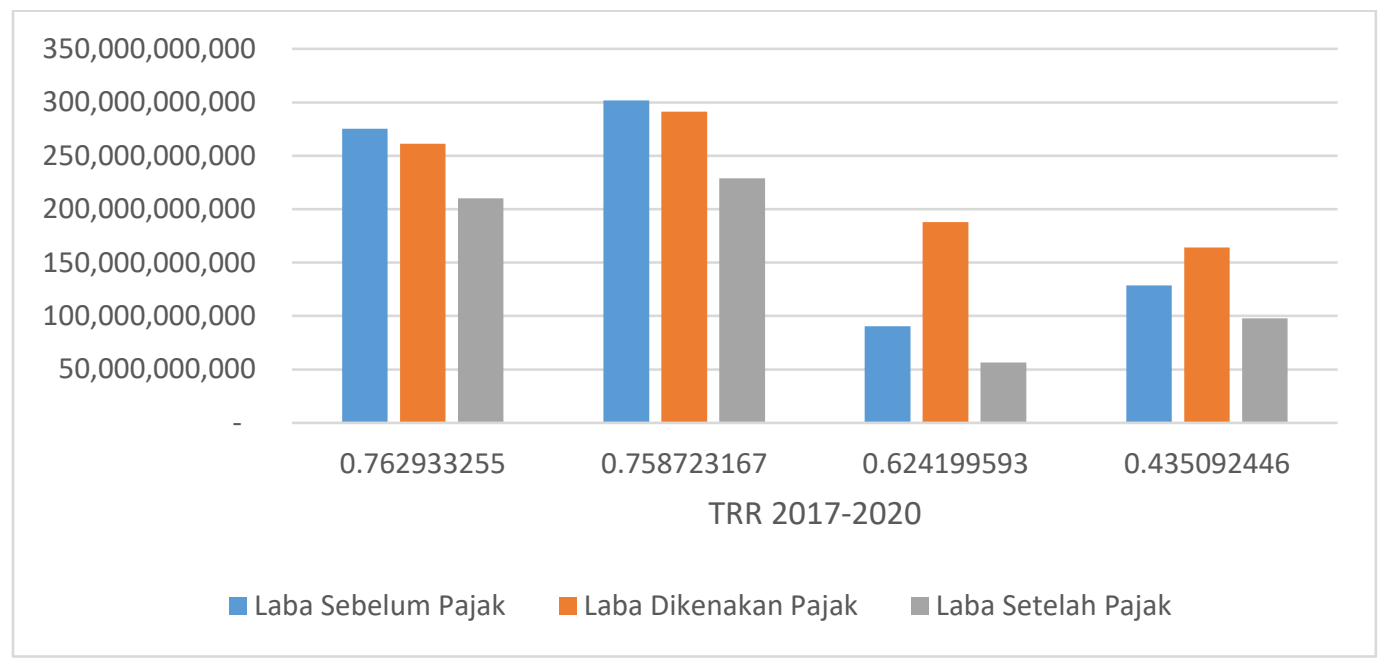

Dari Histogram 1. diketahui bahwa mulai tahun 2018 hingga 2020 nilai TRR semakin menurun setiap tahunnya jika dibandingkan dengan TRR pada tahun 2017. Penurunan yang cukup signifikan terjadi mulai dari tahun 2019 dan 2020, hal ini menunjukkan bahwa perencanaan pajak yang dilakukan oleh manajemen pajak juga melemah. Sama halnya dengan laba perusahaan yang juga mengalami penurunan yang signifikan pada tahun 2019 dan 2020. Sehingga dapat disimpulkan bahwa Ha atau hipotesis alternatif diterima yaitu perencanaan pajak berpengaruh positif terhadap laba perusahaan.

Pada tahun 2019 laba sebelum pajak lebih kecil dibandingkan pada tahun 2020, akan tetapi laba yang dikenakan pajak lebih tinggi dibandingkan tahun 2020, yang berarti bahwa jumlah beban pajak juga tinggi, sedangkan TRR pada tahun 2019 lebih besar dari tahun 2020. Hal ini menerangkan bahwa ada banyak faktor lain yang dapat mempengaruhi pertumbuhan laba perusahaan selain dari perencanaan pajak. Penulis meneliti bahwa faktor terbesar penyebab terjadinya pembengkakan pada laba dikenakan pajak pada tahun 2019 yaitu adanya biaya lain-lain yang dikenakanpajak sebesar 78.603.676. dan faktor besarkedua adalah adanya biaya imbalan paska kerja sebesar 45.867.398. 
\. • P Jurnal Audit \& Perpajakan

Volume : 1 | Nomor 1 | November 2021 | E-ISSN : 2809-1809. | DOI: 10.47709/jap.v1n1.1205

\section{Kesimpulan}

Berdasarkan hasil analisis data tentang perencanaan pajak terhadap laba perusahaan pada PT Sari Enesis Indah tahun 2017-2020, dapat disimpulkan bahwa perencanaan pajak yang dilakukan pada perusahaan tersebut evektif dari tahun 2017-2018 dengan menggunakan perhitungan TRR adalah 0,762933255 dan 0,758723167, akan tetapi efektivitas perencanaan pajak mulai menurun pada tahun 2019-2020 dengan perolehan perhitungan TRR adalah 0,624199593 dan 0,435092446, dengan demikian maka beban pajak pada tahun 2019-2020 mengalami kenaikan dan hal ini berarti bahwa laba yang dihasilkan pada tahun tersebut juga semakin menurun. Maka penulis dapat menyimpulkan bahwa perencanaan pajak berpengaruh positif terhadap laba perusahaan. Akan tetapi faktor yang mengakibatkan penurunan laba bukan hanya karena kurang evektifnya perencanaan pajak yang dilakukan oleh manajemen pajak, tapi banyak juga faktor-faktor lain sebagai pengaruh bagi pertumbuhan laba dalam sebuah perusahaan baik faktor internal, seperti current ratio, net working capital ratio, gross profit margin, return on assets, dan faktor eksternal seperti Inflasi dan wabah virus Covid 19 yang telah melemahkan pertumbuhan laba perusahaan di berbagai sektor bahkan hingga mengalami kerugian.

\section{Referensi}

Achyani, F., Manajemen Laba (Studi Empiris Pada Perusahaan Manufaktur yang Terdaftar \& Lestari, S. (2019). Pengaruh Perencanaan Pajak Terhadap di Bursa Efek Indonesia Tahun 2015-2017). Riset Akuntansi Dan Keuangan Indonesia, 4(1), 77-88.

Dewi, E. R., Nuraina, E., \& Amah, N. (2017). Pengaruh Tax Planning dan Ukuran Perusahaan Terhadap Manajemen Laba (Studi Empiris pada Perusahaan Property yang Terdaftar di Bursa Efek Indonesia). FIPA: Forum Ilmiah Pendidikan Akuntansi, 5(1).

DJP. (2020). Implementasi Penurunan Tarif Pajak Penghasilan Badan dalam Penghitungan PPh Pasal 29 dan Angsuran PPh Pasal 25. Www.Pajak.Go.Id. https://www.pajak.go.id/siaran-pers/implementasipenurunan-tarif-pajak-penghasilan-badan-dalam-penghitungan-pph-pasal-29

Feriyana, F. (2017). PENGARUH PERENCANAAN PAJAK TERHADAP LABA PERUSAHAAN PADA PT MUSTIKA RATU Tbk. Jurnal Online Mahasiswa (JOM) Bidang Akuntansi, 2(2).

Hidayat, N. I. A., Susanti, S., \& Zulaihati, S. (2021). Pengaruh Premi, Hasil Investasi dan Risk Based Capital terhadap Laba Perusahaan Asuransi Syariah Indonesia 2019. Jurnal Akuntansi, Keuangan, Dan Manajemen, 2(4 SE-Articles). https://doi.org/10.35912/jakman.v2i4.552

Muiz, Enong dan Ningsih, H. (2018). Jurnal Ekobis: Ekonomi, Bisnis \& Manajemen Jurnal Ekobis : Ekonomi, Bisnis \& Manajemen. 8, 123-130.

Nugroho, A. C. (2020). Dampak Virus Corona, Aktivitas Manufaktur Indonesia Anjlok ke 45,3 pada Maret. Www.Bisnis.Com. https://ekonomi.bisnis.com/read/20200401/9/1220770/dampak-virus-coronaaktivitas-manufaktur-indonesia-anjlok-ke-453-pada-maret

Peraturan Presiden Republik Indonesia. (2020). Lembaran Negara Republik. Rencana Umum Energi Nasional, 73, 1-6.

Puspitaningtyas, Z. (2017). Efek Moderasi Kebijakan Dividen Dalam Pengaruh Profitabilitas Terhadap Nilai Perusahaan. Jurnal Akuntansi, Ekonomi Dan Manajemen Bisnis, 5(2), 173-180.

Riyanto, S., \& Margie, L. A. (2021). Pengaruh Tax Planning, Kebijakan Hutang Dan Likuiditas Terhadap Nilai Perusahaan. SAKUNTALA: Prosiding Sarjana Akuntansi Tugas Akhir Secara Berkala, 1(1), $175-187$.

Santoso, Y. I. (2020). Penghindaran Pajak Membuat Rugi Negara Rp 68,7 Triliun, ini Kata Dirjen Pajak. Www.Kontan.Co.Id. https://newssetup.kontan.co.id/news/penghindaran-pajak-membuat-ruginegara-rp-687-triliun-ini-kata-dirjen-pajak

Suputra, D. (2017). Pengaruh Mekanisme Corporate Governance dan Beban Pajak Tangguhan terhadap Manajemen Laba (Studi Empiris pada Perusahaan Manufaktur yang Terdaftar di Bursa Efek Indonesia 


\section{- 1 - Jurnal Audit \& Perpajakan}

Volume : 1 | Nomor 1 | November 2021 | E-ISSN : 2809-1809. | DOI: 10.47709/jap.v1n1.1205

Periode 2014-2016). E-Jurnal Akuntansi Universitas Udayana, 20(3), 2045-2072.

UU No. 36 Tahun 2008. (2008). Undang-Undang Republik Indonesia Nomor 36 Tahun 2008 Tentang Perubahan Keempat Atas Undang-Undang Nomor 7 Tahun 1983 Tentang Pajak Penghasilan.

UU RI Tahun 2007 Nomor 28 Tentang Ketentuan Umum dan Tata Cara Perpajakan

Wareza, M. (2020). Gara-gara Rugi Kurs, Laba Pakuwon Jati Ambrol 90\% di Q1-2020. Www.Cnbcindonesia.Com. $\quad$ https://www.cnbcindonesia.com/market/20200626141050-17168312/gara-gara-rugi-kurs-laba-pakuwon-jati-ambrol-90-di-q1-2020

Wirawan, F. W. (2017). Analisis Perencanaan Pajak terhadap Laba Perusahaan (studi pada PT Jamu Air Mancur).

Yuliza, A., \& Fitri, R. (2020). Pengaruh Beban Pajak Tangguhan dan Perencanaan Pajak Terhadap Praktik Manajemen Laba. AKPEM: Jurnal Akuntansi Keuangan Dan Akuntansi Pemerintahan, 2(1), 1-5. 